\title{
THE GOOD (WELL-BEING) OF THE CHILD AND PROCEEDINGS IN CASES OF MINORS IN Polish LAW
}

\begin{abstract}
The subject of the study is to present Polish legal regulations applicable in the case of a minor's demoralization. The ongoing cultural changes of a global nature are conducive to the moral degradation of young people. Human freedom has become the basic value inscribed in the human rights system. This freedom is often abused especially by young people. In addition, transferring human activity to cyberspace to a large extent limits the ability to control the activity of a young person. The aim of this work is to present the statutory definition of the concept of demoralization, its specific cases, and the course of proceedings before a family court in such cases. It is also important to show the attitude of the Polish legislator aimed at saving the minors, and not punishing them. Any penalties imposed on the minors are used as the final measures. The effect of the study is to present the substantive law and the system of dealing with minors before the family court in case of its demoralization.
\end{abstract}

KEYWORDs: minor's rights, demoralization of a minor, Polish law, family court, remedies, well-being of child / minor

\section{INTRODUCTION}

The good (well-being) of the child is a category often referred to in the Polish law. First of all, this concept appears in the Act of $25^{\text {th }}$ February 1964 - the Family and Guardianship Code (consolidated text - Journal of Laws of 2017, item 682). In total, in the Polish family and guardianship code, the concept of child's wellbeing occurs as many as 15 times, most often in connection with the content and exercising the parental authority (Smyczyński, 2018, s. 24-25). 
The good of a child causes that the Polish legislator decided that in the resolution of the way of exercising parental authority over children in the event of divorce of parents, it is the basic criterion in this settled case (article 58, $\$ 1$ of the Family and Guardianship Code - hereinafter: f.g.c.). Even more, the legislator indicates that the best solution is the one which allows siblings to stay together. In the same article, the legislator allowed the court to limit the parental authority of one of the parents because of the child's good (Strzebińczyk, 2016, s. 2246-247).

Parental authority may be limited or included in the verdict determining the origin of the child (article 93, $\$ 2$, f.g.c.). The parental authority itself should be performed as it is required by the good of the child or the social interest (article 95, $₫ 3$ of the f.g.c.). In practice, this means that the child's parents, taking into account his/her mental state, state of health and degree of maturity, should take, if possible, into account minor's reasonable wishes while they are make decisions on more important matters concerning the child's person or property (Smyczyński, 2018, s. 24-25).

\section{THE CONSEQUENCES OF THE LACK OF PARENTAL AUTHORITY}

Wrongly exercised parental authority may lead a child to deform his or her personality. Such a child, often under the influence of the environment or other negative factors, is subject to the process of demoralization. Consequently, such a child is in conflict with the law. For this situation, the Polish legislator provided a separate legal regulation, which contains detailed solutions applied in minor's proceedings. This is the Act of $25^{\text {th }}$ October 2002 on Juvenile Delinquency Proceedings (consolidated text Journal of Laws of 2016, item 1654) (hereinafter: a.j.d.p.) (Kiliańska, 2012, s. 21-32).

The scope of the Act includes regulations regarding the prevention and combating of demoralization - in relation to persons who are under 18 years of age. It also contains regulations on dealing with criminal offenses - in relation to persons who committed such acts after the age of 13, but they did not turn 17 years old and carry out upbringing or correctional measures - in relation to the persons against whom these measures were imposed, but no longer than until they are 21 years old (article $1, \S 1$, a.j.d.p.). 
According to the Polish legislator, the external manifestations of a minor's demoralization include violation of the rules of social coexistence, committing a prohibited act, systematic avoidance of the compulsory school or vocational education, using alcohol or other products causes a state of intoxication, exercising the prostitution, vagrancy or participation in the criminal groups (article $4, \S 1$, a.j.d.p.). The occurrence of a minor's demoralization raises a social obligation to inform the family court or the police about this fact (article $4, \S 2$, a.j.d.p.). In addition, if there are social organizations, they should take appropriate steps to avoid the blurring of evidence of committing a crime (article 4, $\$ 3$, a.j.d.p.) (Haak-Trzuskawska, A., Haak, 2015, Legalis).

The demoralization of a child, however, does not constitute grounds for him or her to be objectified, he or she is still a legal entity and as such, he or she deserves legal protection, he or she is not deprived of any rights of a child or a minor. Thus, the Polish legislator strongly indicates the good of the child in all proceedings in which a demoralized child is being a part. Already, in the article $3, \S 1$ of the a.j.d.p., the legislator says that in cases involving minors, one should be guided by their good. The proceedings are to lead not to punish but to make changes in the personality and behavior of the minor. It is also important that such proceedings should lead to the restoration of the proper exercise of parental authority by the parents. The lack of such power or its improper exercising is the main reason for the child's demoralization. The person conducting the proceedings should also take into account the age, state of health, the level of psychological and physical development, the character, as well as behavior and causes and degree of demoralization, the nature of the environment and the conditions for bringing up the minor (article 3, $\$ 2$ a.j.d.p.) (Korcyl-Wolska, 2008, s. 15).

The well-being of the child also inclines to the fact that at any stage of the proceedings, the family court, on the initiative or with agreement of victim and the minor, take mediation. Thus, the court may refer the case to a trustworthy institution or person for mediation (article $3 a, \S 1$, a.j.d.p.) (Such-Pyrgiel, 2012, s. 13 n.). 


\section{MEASURES TO PREVENT AND TO COMBAT THE JUVENILE'S DEMORALIZATION AND DELINQUENCY}

The degree of demoralization of a minor is sometimes quite significant. It is not possible to change the personality or behavior of the minor except by taking specific actions with the help of a family court or other environmental activities. As a rule, the educational measures and a corrective measure in the form of placement in a correctional facility may be used against the minor. In addition, the punishment can only be imposed only in the cases provided by law, if other means are not able to ensure the juvenile's social rehabilitation (article 5, a.j.d.p.) (Bojarski, Kruk, Skrętowicz, 2011, s. 54 n.).

The Polish legislator provided the following measures to combat and prevent the demoralization of a minor who may be taken against a minor by a family court (article 6, a.j.d.p.):

1) to give a warning;

2) to oblige to perform specific proceedings, in particular to remedy the damage caused, to perform specific work or services for the victim or local community, to apologize to the victim, to study or to work, to participate in appropriate educational, therapeutic or training activities, to stop from staying in certain environments or places or to stop using alcohol or other substance causing the state of intoxication;

3) to establish responsible supervision of the parents or guardian;

4) to establish supervision of a youth organization or other social organization, workplace or trustworthy person who are providing guarantees for a minor;

5) to apply the probation officer's supervision;

6) to send to a probation center, as well as to social organization or institutions dealing with work with minors of an educational, therapeutic or training character, after prior consultation with that organization or institution;

7) to decided about a ban on driving vehicles;

8) to decide about forfeiture of things obtained in connection with the punishable offense;

9) to decided about placing the youth educational center or a professional foster family who have completed a training course to provide care for minors; 
10) to decided about sending to the correction center;

11) to apply other measures as provided for in this Act under the jurisdictionof the family court, as well as to apply the measures provided for in the Family and Guardianship Code, excluding placement in a foster family who is related to minor, foster family who is not professional, family children's home, day care facility, care and educational institution and regional care and therapeutic facility.

In addition, the family court may also take other remedies (article 7, a.j.d.p.):

1) to oblige the parents or guardian to improve the upbringing, staying or health care conditions of minor, as well as to closely cooperate with the school to which the minor attends, with psychological and pedagogical counseling institution or with other specialist clinic, with the workplace in which he or she is employed, and with a doctor or medical facility;

2) to oblige the parents or guardian to repair in whole or in part the damage caused by the minor.

The court may request appropriate state or social institutions and local government units to provide the necessary assistance in improving the juvenile's upbringing, living or health conditions.

In extreme cases, the family court may place the minor in a correctional institution if he or she has committed a punishable offense with the high degree of demoralization and ordinary remedies do not promise improvement (article 10, a.j.d.p.). Such court order may be suspended if the personal and environmental characteristics and conditions as well as the circumstances and nature of his or her act justify the assumption that despite the failure to implement a corrective measure, the educational objectives will be achieved (article 11, a.j.d.p.). During this period, the educational measures are applied. When a minor shows the characteristics of mental retardation, mental illness or other disruption of mental activities or compulsive use of the alcohol or other substance causes a state of intoxication, the family court may order the placement of a minor in a psychiatric hospital or other appropriate treatment facility (article 12, a.j.d.p.) (Haak, 2017, s. 399 n.). 


\section{The COURSE OF PROCEEDINGS IN JUVENILE CASES}

Proceedings in the juvenile cases are rather analogical as in the situations of adults whose case is being proceeded before a criminal court. In this situation, the case is proceeded before a family court. The proceedings start with determining the person concerned and the subject of the proceedings. The summoning request is delivered to the parties of the proceedings along with instructions about their rights and obligations incumbent on them (article 32a, a.j.d.p.) (Górecki, Stachowiak, 2007, s. 65 n.) (Krajewska, 2016, s. 129 n.).

The collection of evidences is the next part of the proceedings before a family court. The data concerning the minor, the conditions of his or her upbringing and health conditions are collected. The court may hear a minor, as well as his or her parents or guardian. In special cases, it may order a search of the minor's staying place and may use other procedural steps to provide a comprehensive explanation of the case. The parties, advocates and proxies may submit evidence requests. The aggrieved party (victim) may submit proofs till the beginning of the hearing or the meeting (article 32b, a.j.d.p.).

In order to defend the interests of a minor and his or her family or guardian, the family court may appoint a public defender. Similarly, a court may act in the cases where a minor has not a defender, he or she is deaf or blind, or when there is justified doubt as to whether his or her mental health condition allows him or her to participate in the proceedings or conduct a defense in an independent and reasonable manner. In addition, a minor may apply to the court for the establishment of a public defender. Such a defender may only act to defend the interests of the minor. In other words, he or she cannot perform procedural actions that would charge a minor (art 32c, a.j.d.p.).

The police gather information about the activities of the minor and, if necessary, it may detain the minor (article 32e, $₫ 1$, a.j.d.p.). The actions taken by the Police are most often carried out at the court's request (article 32 e, $\$ 2$, a.j.d.p.). The interrogation of a minor who is carried out by the Police is a special activity. The hearing of a minor by the Police takes place in the presence of parents who are entitled to parental responsibility, or a guardian or defender of a minor. In the situation when those people cannot participate in the process of interviewing a minor, a close relative, a school 
representative to which the minor attends, a family assistant, a foster family coordinator or a representative of a social organization, whose statutory tasks include the educational impact on minors or supporting the process of their resocialization should be called (article 32f, a.j.d.p.).

After conducting the evidentiary proceedings, there is a normal hearing at the closed door, to which the parties and the aggrieved party are summoned, if such is the case (article 32l, a.j.d.p.). A public hearing is admissible only when it is related to the educational aspects.

At the hearing, the family court listens to the minor. The minor can make comments and make statements regarding every evidence they have taken. The environmental interviews and opinions about minors should be read during minor's absence, unless special educational reasons speak for the purpose of acquainting the minor with their content (article 32n, a.j.d.p.). The parties' failure to appear in court does not stop the trial. However, it is not possible to conduct a hearing in the absence of a minor, if he or she justified his or her absence (article 32o, a.j.d.p.).

The court hearing ends with a decision in which the family court states whether the minor shows the signs of demoralization or committed an offense, and decides on the application of the measures specified in the article 6 of the a.j.d.p. (article 32r, a.j.d.p.).

\section{Conclusions}

Presented above the legal status on Polish legislation regarding minors who have undergone a process of demoralization shows that it is in the line with European standards. In the first place, there is the well-being of the minor and the use of such means that he or she will be a subject of resocialization. Punishing a minor is the last measure when others are already failing. It should be noted that proceedings in juvenile cases end with a decision and not with a verdict.

In order to protect the well-being (good) of a minor, the legislator introduced a fairly wide range of remedies that are sufficient. The minor has guaranteed rights of defense, including a public defender. The legislator has also introduced a number of institutions to protect the minor, including at the stage of gathering evidence of demoralization (Krajewska, 2018, s. 31 n.). 
It should be noted that Polish legislation protects juveniles fairly well and reacts in a correct manner to all forms of demoralization of persons who are to be good and fully-fledged citizens of Poland in the future.

\section{References}

Bojarski, E. Kruk, T., Skrętowicz, E. (2016). Ustawa o postępowaniu w sprawach nieletnich. Komentarz, Warszawa: LexisNexis. ISBN 9788380923102.

Górecki, P., Stachowiak, S. (2007). Ustawa o postępowaniu $w$ sprawach nieletnich, Warszawa: Wolters Kluwer. ISBN 9788375262049.

Haak-Trzuskawska, A., Haak, H. (2015). Ustawa o postępowaniu w sprawach nieletnich. Komentarz, Warszawa: Legalis. ISBN 9788325574420

Haak, H. (2017). Postępowanie w sprawach dotyczacych kontaktów z dzieckiem - wybrane zagadnienia, [w:] Źyłko W. (red.), Człowiek. Państwo. Prawo. Księga Jubileuszowa dedykowana Stanisławowi Leszkowi Stadniczeńko, s. 399-416l Warszawa: Wyższa Szkoła Finansów i Zarządzania w Warszawie. ISBN 9788388953279.

Kiliańska, A. (2012). Ograniczenie władzy rodzicielskiej, Przegląd PrawnoEkonomiczny nr 18, s. 21-32. ISSN 1898-2166.

Korcyl-Wolska, M. (2008). Postępowanie w sprawach nieletnich. Warszawa: Wolters Kluwer. ISBN 9788376012292.

Krajewska, A. (2016). Kryzys edukacyjny a trudności szkolne dziecka powodowane przetrwalymi odruchami, Journal of Modern Science 28/1, s. 127-140. ISSN 17342031.

Krajewska, A. (2018). Wychowanie do wartości w społeczeństwie niepewnych wartości, Journal of Modern Science 36/1, s. 27-40. ISSN 1734-2031.

Smyczyński, T. (2018). Prawo rodzinne i opiekuńcze, Warszawa: Wydawnictwo C.H. Beck. ISBN 9788381282376.

Strzebinczyk, J.F. (2016). Prawo rodzinne, Warszawa: Wolters Kluwer. ISBN 9788380924116.

Such-Pyrgiel, M. (2012). Rodzina i jakość życia we wspótczesnym społeczeństwie polskim. Zarys problematyki, [w:] M. Sitek, M. Such Pyrgiel, D. Przastek, Bezpieczeństwo i jakość życia we współczesnym społeczeństwie polskim. Studium interdyscyplinarne, s. 13-33. Józefów: WSGE. ISBN 9788362753628. 